\title{
Morphogenesis of Mammary Glands in Buffalo (Bubalus bubalis)
}

\author{
Amit Challana, Anuradha Gupta, Neelam Bansal, and Varinder Uppal \\ Department of Veterinary Anatomy, College of Veterinary Sciences, Guru Angad Dev Veterinary \\ and Animal Sciences University, Ludhiana, Punjab 141004, India \\ Correspondence should be addressed to Anuradha Gupta; anuradha71@in.com
}

Received 19 February 2014; Revised 21 March 2014; Accepted 8 April 2014; Published 27 April 2014

Academic Editor: Fred Sinowatz

Copyright (C) 2014 Amit Challana et al. This is an open access article distributed under the Creative Commons Attribution License, which permits unrestricted use, distribution, and reproduction in any medium, provided the original work is properly cited.

The present research was elucidated on the morphogenesis of mammary gland of buffalo during prenatal development. Total of 16 foetuses ranging from $1.2 \mathrm{~cm}$ (34 days) to $108 \mathrm{~cm}$ CVRL (curved crown rump length) (317 days) were used for study. The study revealed that mammary line was first observed at $1.2 \mathrm{~cm}$ CVRL ( 34 days), mammary hillock at $1.7 \mathrm{~cm}$ ( 37 days), and mammary bud at $2.6 \mathrm{~cm}$ CVRL ( 41 days) foetuses. Epidermal cone was found at $6.7 \mathrm{~cm}$ CVRL ( 58 days) whereas primary and secondary ducts were observed at $7.4 \mathrm{~cm}$ CVRL (62 days) and $15 \mathrm{~cm}$ CVRL (96 days), respectively. Connective tissue whorls were reported at 18.2 cm CVRL (110 days) and internal elastic lamina and muscle layers at $24.1 \mathrm{~cm}$ CVRL (129 days). Lobules were observed at $29.3 \mathrm{~cm}$ CVRL (140 days), rosette of furstenberg at $39.5 \mathrm{~cm}$ CVRL (163 days), and keratin plug at $45.5 \mathrm{~cm}$ CVRL (176 days) foetus. Primordia of sweat and sebaceous glands around hair follicle were seen at $21.2 \mathrm{~cm}$ CVRL (122 days) of foetal life. Differentiation of all the skin layers along with cornification was observed at $69 \mathrm{~cm}$ (229 days) in group III foetuses.

\section{Introduction}

The latest trend in search of food leads to tremendous scope of livestock industry to develop breeds having more milk yield [1]. Milk is an excellent source of vitamins and minerals for the human diet [2]. The profit of livestock industry is directly related to maximum milk production from animals [1]. Optimizing the process of milk production will benefit consumers, producers, and the animals involved by increasing production efficiency and improving animal health [3].

India's status as the largest milk producing country in the world is attributed to its large bovine population comprising of 210.2 million cattle and 111.3 million buffaloes. Buffalo milk production in India is 62.4 million tonnes which is about $67.40 \%$ of total world (92.51 million tonnes) (FAOSTAT, 2010). Buffalo has been an integral part of livestock economy for over 5000 years providing draft power, milk, meat, and hides [4]. In India, buffaloes are preferred over cattle as a dairy animal and are eulogized as "the black gold of India" because of high milk fat content which fetches higher market price [5].
The global economic value of buffalo is tremendous and ultimately hinges on its mammary glands, either through its capacity to provide dairy products or because of its growth and production of milk which underlies successful animal production, welfare, and survival [6]. Milk yield and shape of lactation curve are determined by the number of mammary secretory cells and the secretory activity per cell [7].

During the lifetime of the animal the mammary gland probably undergoes more and greater changes in size, structure, composition, and activity than any other tissue or organ. These changes start during foetal life and continue even after the gland has reached maturity since it waxes and wanes during successive reproductive cycles [8]. The basic structures of the mammary glands are formed in foetal life and comprise a system of growing ducts that are confined to a very limited area around the teat or the gland [9].

The detailed histomorphological studies have been reported on morphogenesis of sheep [9] and goat [10-12], but scanty information is available on development of mammary gland at different stages of prenatal life in buffalo. 
To improve efficiency of milk production, we must understand the mechanisms involved in mammary development stages of buffalo during foetal life. Hence, the morphogenesis of mammary tissue may reveal the ways to manipulate the development of mammary gland to enhance milk production in mature buffalo.

\section{Materials and Methods}

2.1. Collection of Samples. The present study was conducted on mammary glands of 27 buffalo foetuses. The foetuses of different gestational age were obtained from pregnant nondescript buffaloes slaughtered at Gazipur Slaughter House, New Delhi, and Veterinary Clinical Complex, GADVASU, Ludhiana. The tissue samples were collected after death/slaughter of the animals. The particulars of foetuses have been described in Table 1. After the collection, the foetal body length was measured as curved line in centimeter with the help of inelastic thread along the vertebral column between the most anterior part of frontal bone to the rump at ischiatic tuberosity and designated as crown rump length [13].

The approximate age of the foetuses was calculated by using the formula [14]

$$
\begin{gathered}
Y=28.66+4.496 X(\mathrm{CVRL}<20 \mathrm{~cm}) \\
Y=73.544+2.256 X(\mathrm{CVRL} \geq 20 \mathrm{~cm}),
\end{gathered}
$$

where $Y$ is age in days and $X$ is CVRL in centimeters.

Based on CVRL the foetuses were divided into three groups:

group I: foetuses of CVRL between 0 and $20 \mathrm{~cm}$; group II: foetuses of CVRL between 20 and $40 \mathrm{~cm}$; group III: foetuses of CVRL above $40 \mathrm{~cm}$.

2.2. Fixation and Processing. The small pieces of $1.0 \mathrm{~cm}$ thickness were collected for histomorphological studies. In small sized foetuses up to $2.6 \mathrm{~cm}$ CVRL the whole amount was taken as it is difficult to collect mammary glands at this age. In the foetuses from 6.7 to $110 \mathrm{~cm}$ CVRL teats with glandular portion were taken out and serial sectioning was done on the foetuses/mammary gland samples.

The tissue samples were fixed in 10\% neutral buffered formalin (NBF) immediately after collection. Once the fixation was achieved, the tissues were processed for paraffin block preparation by acetone-benzene schedule [15]. The blocks were prepared and sections of 5-6 $\mu \mathrm{m}$ thickness were cut and obtained on clean glass slides with rotary microtome. The paraffin sections were stained with Hematoxylin and Eosin stain [15] to study the morphogenesis.

\section{Results}

Mammary gland develops from the ectoderm and mesoderm germ layers in the embryonic life. The cells differentiated to develop into the functional mammary gland occurred during the early foetal life.

\begin{tabular}{|c|c|c|c|c|}
\hline Sr. number & Group & $\begin{array}{l}\text { Animal } \\
\text { number }\end{array}$ & $\begin{array}{l}\text { CVRL } \\
(\mathrm{cm})\end{array}$ & $\begin{array}{l}\text { Estimated } \\
\text { age (days) }\end{array}$ \\
\hline 1 & Group I & $\mathrm{A} 1$ & 1.2 & 34 \\
\hline 2 & -do- & A2 & 1.7 & 37 \\
\hline 3 & -do- & A3 & 2.6 & 41 \\
\hline 4 & -do- & $\mathrm{A} 4$ & 6.7 & 58 \\
\hline 5 & -do- & A5 & 7.4 & 62 \\
\hline 6 & -do- & A6 & 10.7 & 77 \\
\hline 7 & -do- & A7 & 12.6 & 85 \\
\hline 8 & -do- & $\mathrm{A} 8^{*}$ & 15 & 96 \\
\hline 9 & -do- & A9 & 18.2 & 110 \\
\hline 10 & Group II & $\mathrm{B} 1^{*}$ & 20.1 & 119 \\
\hline 11 & -do- & B2 & 21.2 & 122 \\
\hline 12 & -do- & B3 & 24.1 & 130 \\
\hline 13 & -do- & B4 & 29.3 & 140 \\
\hline 14 & -do- & $B 5^{*}$ & 32 & 146 \\
\hline 15 & -do- & B6 & 39.5 & 163 \\
\hline 16 & Group III & $\mathrm{Cl}^{*}$ & 43 & 172 \\
\hline 17 & -do- & $\mathrm{C} 2$ & 45.5 & 176 \\
\hline 18 & -do- & $\mathrm{C} 3$ & 47.8 & 181 \\
\hline 19 & -do- & $\mathrm{C} 4^{*}$ & 58 & 204 \\
\hline 20 & -do- & $\mathrm{C} 5$ & 69 & 229 \\
\hline 21 & -do- & $\mathrm{C} 6^{*}$ & 74 & 241 \\
\hline 22 & -do- & $\mathrm{C} 7$ & 82 & 259 \\
\hline 23 & -do- & $\mathrm{C} 8$ & 89.5 & 275 \\
\hline 24 & -do- & $\mathrm{C} 9^{*}$ & 94 & 286 \\
\hline 25 & -do- & $\mathrm{C} 10$ & 102 & 303 \\
\hline 26 & -do- & C11 & 108 & 317 \\
\hline 27 & -do- & $\mathrm{C} 12$ & 110 & 320 \\
\hline
\end{tabular}

TABLE 1: Details of buffalo foetuses used in study.

The samples marked by " $*$ " have been collected from Veterinary clinics, GADVASU Ludhiana.

3.1. Mammary Line. The earliest recognizable stage of mammary gland development in the present study was mammary line found in $1.2 \mathrm{~cm}$ CVRL (34 days) buffalo foetus on the ventral side in the inguinal region posterior to umbilicus (Figure 1). The proliferation of mesenchymal cells resulted in condensation of mammary line into cone shaped mammary hillock at $1.7 \mathrm{~cm}$ CVRL (37 days) of foetal age (Figure 2).

3.2. Mammary Bud. The mammary bud is the most prominent stage of mammary embryonic development in buffaloes. It was observed in $2.6 \mathrm{~cm}$ CVRL (41 days) buffalo foetus (Figure 3). It was ovoid in shape with its long axis perpendicular to the surface of the foetus.

3.3. Primary Sprout. The mesenchymal cells surrounding the mammary bud apparently proliferated to form the ventral projection of mammary tissue which developed to epidermal cone (primitive teat) at $6.7 \mathrm{~cm}$ CVRL (58 days) in the inguinal region of buffalo foetus (Figure 4 ). The epidermal cells of the bud presumably were elongated by rapid cell proliferation 


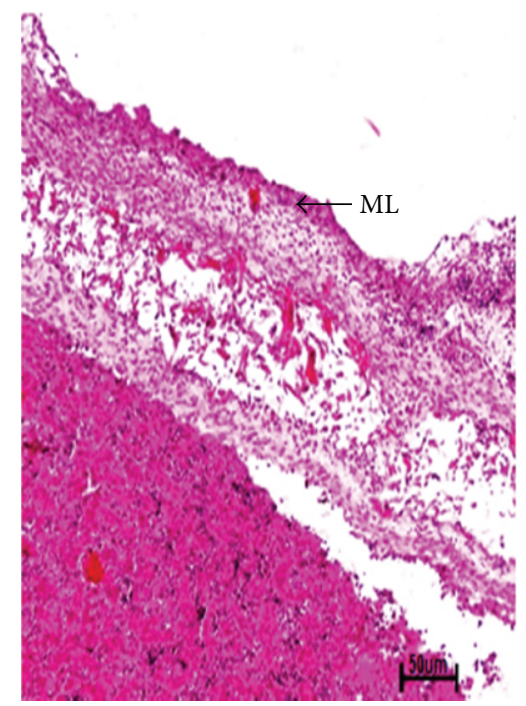

Figure 1: Photomicrograph of mammary line (ML) of buffalo foetuses in the ventral region at $1.2 \mathrm{~cm}$ CVRL (34 days). Hematoxylin and Eosin stain $\times 100$.

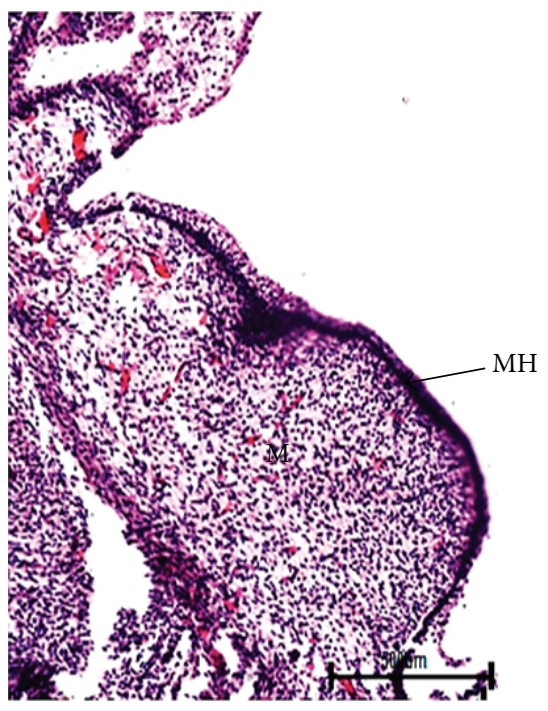

Figure 2: Photomicrograph of mammary hillock (MH) of buffalo foetuses at $1.7 \mathrm{~cm}$ CVRL (37 days). Hematoxylin and Eosin stain $\times 100$.

into the underlying mesenchymal tissue along the length of the teat to form primary sprout at $7.4 \mathrm{~cm}$ CVRL (62 days) of foetal age (Figure 5). These cells got extended as cellular chords and entered deep into the base of teat at $10.7 \mathrm{~cm}$ CVRL (77 days) of foetal age. At $10.7 \mathrm{~cm}$ CVRL (77 days), luminization of the primary duct was observed in the area of primary sprout leading towards the teat. The luminization of primary sprout towards the apex of the teat on the distal end and towards the gland sinus proximally was observed in $12.6 \mathrm{~cm}$ CVRL (85 days) of buffalo foetus. The primary duct gave rise to the teat cistern, gland cistern, and major duct system of mammary gland (Figure 6).

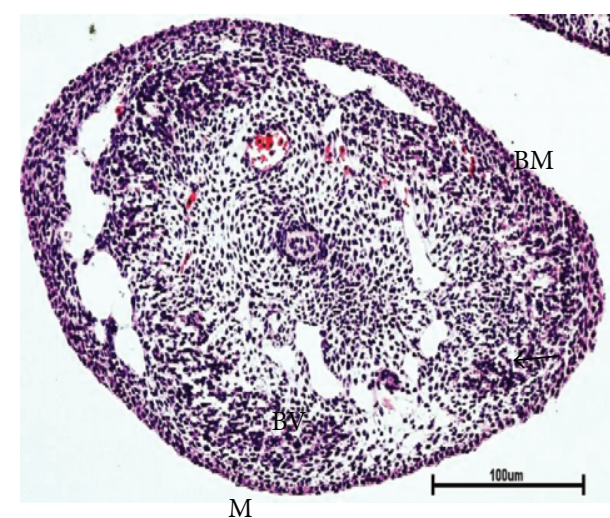

FIGURE 3: Photomicrograph of mammary bud of buffalo foetuses showing concentric layers of mesenchymal cells and blood vessel (BV) lined by basement membrane (BM) at $2.6 \mathrm{~cm}$ CVRL (41 days). Hematoxylin and Eosin stain $\times 100$.

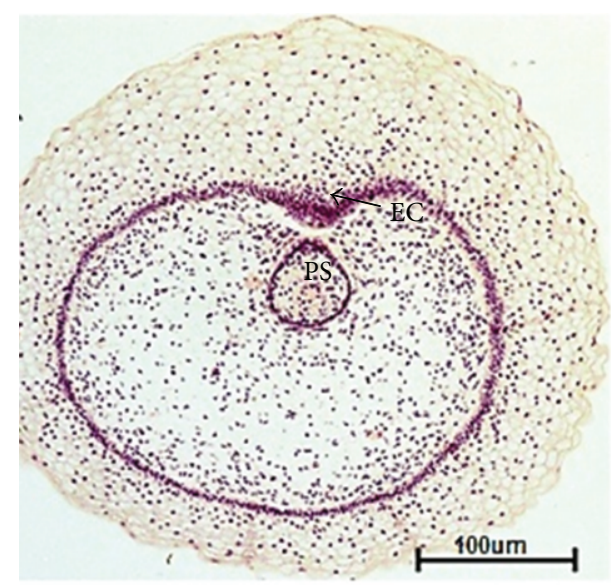

FIgURE 4: Photomicrograph of primary sprout (PS) and epidermal cone (EC) at $6.7 \mathrm{~cm} \mathrm{CVRL} \mathrm{(58} \mathrm{days).} \mathrm{Hematoxylin} \mathrm{and} \mathrm{Eosin} \mathrm{stain}$ $\times 40$.

3.4. Secondary Sprout. The secondary ducts appeared as irregular shaped hollow sacks at $15 \mathrm{~cm}$ CVRL (96 days) of foetal age (Figure 7). These ducts would form the duct system of the mammary gland. The lumen of secondary ducts began to develop by cellular degeneration of epithelial cells of primary sprout at various angles into the surrounding mesenchyme at $18.2 \mathrm{~cm}$ CVRL (110 days) (Figure 8).

The secondary ducts gave rise to tertiary branches at $21.2 \mathrm{~cm}$ CVRL (122 days) and further branching of the tertiary ducts was observed at $24.1 \mathrm{~cm}$ CVRL (130 days) that proceeded towards the fat pad.

3.5. Teat Formation. As the age advanced, gradually the epidermal cone got elevated along the mammary bud and the development of teat was initiated at $6.7 \mathrm{~cm}$ CVRL (58 days). With increasing age, the length of teat also increased.

3.6. Fat Pad. The mesenchymal cells at the base of developing mammary gland differentiated into fat pad at $45.5 \mathrm{~cm}$ CVRL (176 days) of buffalo foetus. 


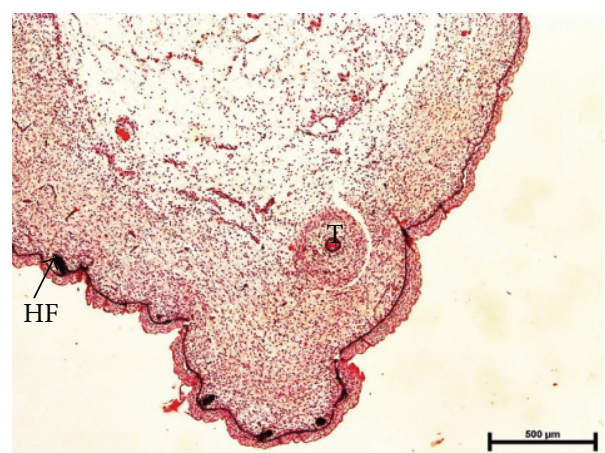

FIGURE 5: Photomicrograph of initiation of teat development along with epidermis, dermis, gland sinus, and hair follicle (HF) at $7.4 \mathrm{~cm}$ CVRL (62 days). Hematoxylin and Eosin stain $\times 40$.

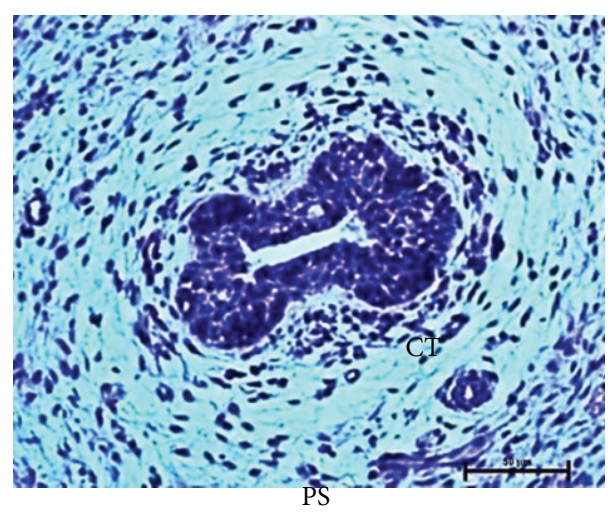

FIGURE 6: Photomicrograph of luminized primary sprout (PS) surrounded by connective tissue (CT) at $12.6 \mathrm{~cm}$ CVRL ( 85 days). Hematoxylin and Eosin stain $\times 400$.

3.7. Gland Cistern. The initiation of gland cistern was observed in $15 \mathrm{~cm}$ CVRL (96 days) buffalo foetus. The continual growth of the lumen of the primary sprout pushed back the cells lining the primary sprout towards glandular tissue of developing mammary gland resulting in formation of fully developed gland cistern at $47.8 \mathrm{~cm}$ CVRL (181 days) in buffalo foetuses (Figure 10).

3.8. Teat Cistern. The canalization of primary sprout proceeded downward and initiated the formation of teat cistern in $15 \mathrm{~cm}$ CVRL (96 days) of buffalo foetus. Well distinct teat cistern was noticed at $21.2 \mathrm{~cm}$ CVRL (122 days). The lumen of teat cistern continued downward to form teat canal at $21.2 \mathrm{~cm}$ CVRL (122 days) of buffalo foetus.

The rosette of furstenberg was observed at $39.5 \mathrm{~cm}$ CVRL (163 days) at junction of teat canal and streak canal (Figure 9) and keratin plug was found at $45.5 \mathrm{~cm}$ CVRL (176 days) of buffalo foetuses (Figure 11).

3.9. Microvascularization. The blood vessels were observed in the mesenchymal tissue of mammary bud at $2.6 \mathrm{~cm}$ CVRL (41 days) of buffalo foetus. At $18.2 \mathrm{~cm}$ CVRL (110 days), nerves

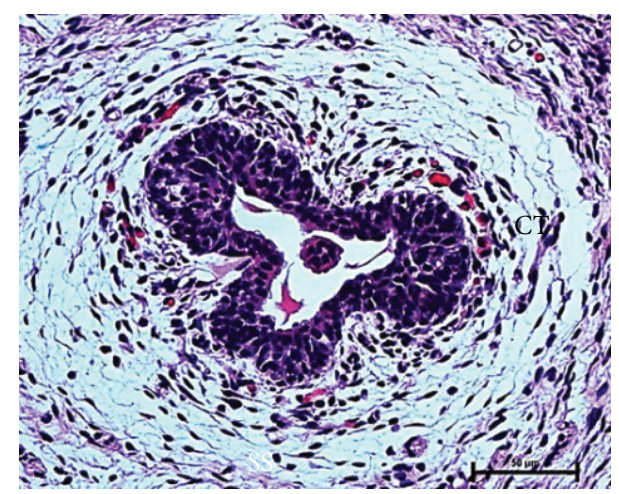

FIGURE 7: Photomicrograph of secondary sprout (SS) at $15 \mathrm{~cm} \mathrm{CVRL}$ (96 days). Hematoxylin and Eosin stain $\times 400$.

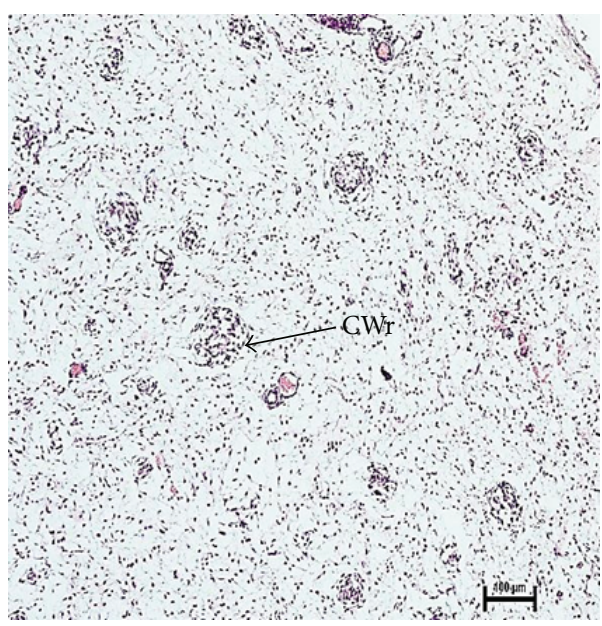

FIGURE 8: Photomicrograph connective tissue whorl (CWr) at $18.2 \mathrm{~cm}$ CVRL (110 days). Hematoxylin and Eosin stain $\times 100$.

and small blood vessels were found in close association with connective tissue whorl (Figure 8).

With advancement of foetal age the numerous blood vessels were seen around secondary sprout, developing gland, and teat cistern. At $69 \mathrm{~cm}$ CVRL (229 days), blood and lymphatic vessels along with nerve bundles were present throughout the mammary gland.

3.10. Skin and Its Appendages. The skin was comprised of distinct epidermis and dermis at $6.7 \mathrm{~cm}$ CVRL (58 days) buffalo foetuses. Epidermis was $4-5$ cell layers thick at $6.7 \mathrm{~cm}$ CVRL (58 days) which was increased to 7-8 cell layers at $7.4 \mathrm{~cm}$ CVRL (62 days) and 12-14 at $10.7 \mathrm{~cm}$ CVRL (77 days). With advancement of fetal age thickness of epidermis decreased and became 4-5 cell layers at $18.2 \mathrm{~cm}$ CVRL (110 days). Dermis was clearly divided in two layers at $18.2 \mathrm{~cm}$ CVRL (110 days). Outer layer that is towards epidermis was loosely arranged, whereas the inner layer was dense. The thickness of dermis increased with advancement of fetal age. Primordia of hair follicle were observed in $6.7 \mathrm{~cm}$ CVRL (58 days) buffalo fetus. Primordia of sweat and sebaceous glands were found at $21.2 \mathrm{~cm}$ CVRL (122 days) of buffalo 


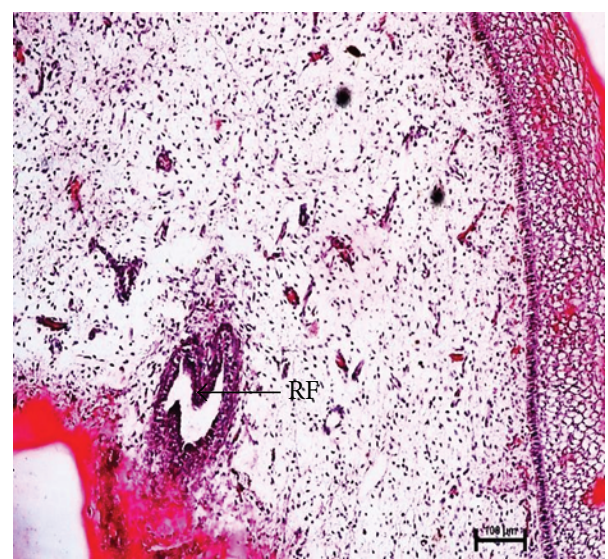

FIGURE 9: Photomicrograph of rosette of furstenberg (RF) at $39.5 \mathrm{~cm}$ CVRL (163 days). Hematoxylin and Eosin stain $\times 100$.

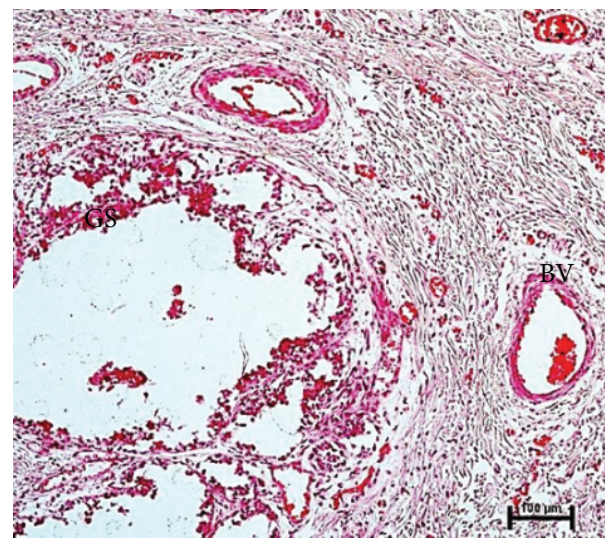

FIGURE 10: Photomicrograph of gland sinus (GS) surrounded by blood vessels (BV) at $47.8 \mathrm{~cm}$ CVRL (181 days). Hematoxylin and Eosin stain $\times 100$.

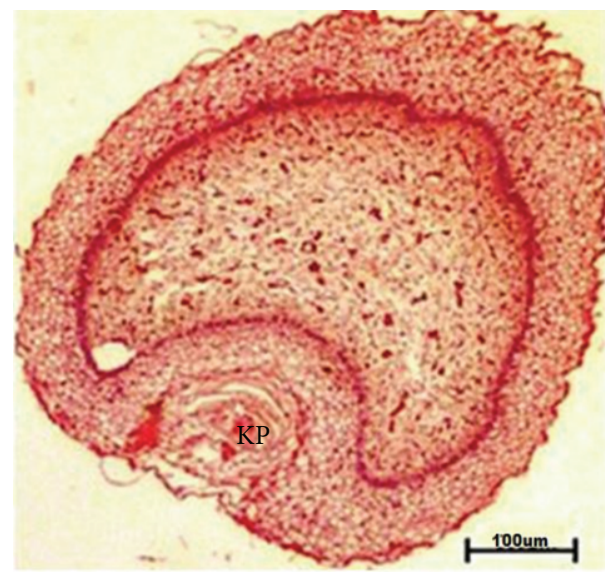

FIGURE 11: Photomicrograph of keratin plug at tip of teat in $45.5 \mathrm{~cm}$ CVRL (176 days). Hematoxylin and Eosin stain $\times 40$.

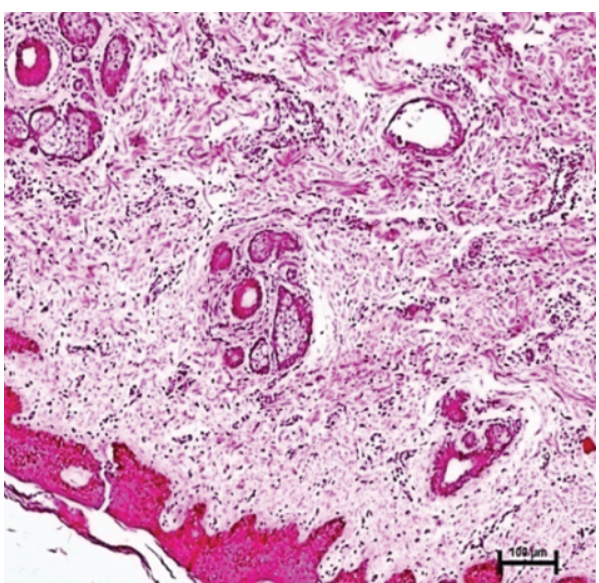

Figure 12: Photomicrograph of hair follicle surrounded by sebaceous gland and sweat glands at $82 \mathrm{~cm}$ CVRL (259 days). Hematoxylin and Eosin stain $\times 100$.

fetus. From $69 \mathrm{~cm}$ CVRL (days) onwards, epidermis was fully developed as in adult at streak canal and around mammary gland (Figure 12).

\section{Discussion}

The development of the mammary gland is a continuous process throughout life that begins when the animal is a foetus and continues through adulthood [16]. It starts as thickening of ectodermal cells on the ventral surface of the embryo giving rise to the mammary band. As proliferation of the ectoderm cells and mesenchymal cells continues, the mammary band develops into mammary streak, mammary hillock, and ultimately into mammary bud.

Mammary band developed at $9 \mathrm{~mm}$ CRL in sheep, $5 \mathrm{~mm}$ CRL in goat, and $14 \mathrm{~mm}$ CRL in cattle [17]. Similarly, [18, 19] observed that the mammary gland formed from an invagination of ectoderm at $1.4 \mathrm{~cm}$ CVRL in cow embryo. The mammary band runs along both sides of the midline in the inguinal region at day 40 in sheep foetuses [9].

Mammary line appeared in the inguinal region on either side of midventral line, medial to thigh at 38 days $(1.0 \mathrm{~cm}$ CRL) in buffalo foetuses [20], whereas Singh (2000) observed four mammary anlages on the ventral abdominal wall caudal to umbilicus between the hind limbs in buffalo foetus at 90109 days of gestation.

The mammary line was observed in the inguinal area posterior to umbilicus at 40 days in sheep foetuses [9]. The mammary line extended from the forelimb buds to the hind limb buds at 30 days of gestation in bovine foetus [21]. The median line was observed medial to thigh in $4.50 \mathrm{~cm}$ CRL and was discoid shaped mammary crest in $5.00 \mathrm{~cm}$ CRL goat foetuses [11].

Mammary bud was found at $3.0 \mathrm{~cm}$ CRL in cow foetuses [18]. The mammary bud was most often elongated and ovoid in shape in cattle embryo [22].

The mammary hillock and bud were the prominent stages of mammary embryonic development in ruminants [19]. In 
TABLE 2: Summary of morphogenesis in buffalo foetal mammary gland.

\begin{tabular}{|c|c|c|c|c|c|}
\hline Sr. number & Structure developed & $\begin{array}{l}\text { CVRL }(\mathrm{cm}) \\
\text { buffalo }\end{array}$ & $\begin{array}{l}\text { Age (days) } \\
\text { buffalo }\end{array}$ & $\begin{array}{l}\text { CRL (mm) } \\
\text { cattle }\end{array}$ & $\begin{array}{l}\text { Age (days) } \\
\text { cattle }\end{array}$ \\
\hline 1 & Mammary line & 1.2 & 34 & 17 & 35 \\
\hline 2 & Mammary hillock & 1.7 & 37 & 21 & 40 \\
\hline 3 & Mammary bud & 2.6 & 41 & 25 & 43 \\
\hline 4 & Epidermal cone and primary sprout & 6.7 & 57 & - & - \\
\hline 5 & Developed teat & 7.4 & 62 & 80 & 65 \\
\hline 6 & Luminized primary sprout & 10.7 & 77 & 120 & 80 \\
\hline 7 & Secondary sprout & 15 & 96 & 160 & 90 \\
\hline 8 & Connective tissue whorls & 18.2 & 110 & - & - \\
\hline 9 & Teat cistern and internal elastic lamina & 24.1 & 128 & 300 & 130 \\
\hline 10 & Lobules and interlobular septa & 29.3 & 140 & - & - \\
\hline 11 & Rosette of furstenberg & 39.5 & 163 & - & - \\
\hline 12 & Keratin plug, fat pad, and gland cistern & 45.5 & 176 & - & - \\
\hline 13 & Well-developed Teat canal & 47.8 & 181 & - & - \\
\hline 14 & Well-developed sweat and sebaceous gland & 82 & 258 & - & - \\
\hline
\end{tabular}

Jenkinson (2003)[9].

buffalo and bovine foetuses mammary bud was noticed at 55 days $(4.20 \mathrm{~cm}$ CVRL) and 43 days, respectively [20,23], whereas [9] mammary bud was found at 40 days in sheep foetuses (Table 2). However, the mammary bud lengthened and branched from day 58 onwards in bovines [24].

Formation of mammary bud was observed between 4.4 and $6.0 \mathrm{~cm}$ CRL (44-49 days) and the cells of the mammary bud progressed deeper into the dermis at $7.9 \mathrm{~cm} \mathrm{CRL}$ in goat foetus [25].

The primary duct was found at $12.00 \mathrm{~cm}$ CRL in cow foetuses [18]. It got elongated and entered deep into the teat base at 102 days $(14.30 \mathrm{~cm} \mathrm{CRL})$ [20]. The luminization progressed towards the distal end of the duct near the teat apex in 120 days $(18.50 \mathrm{~cm} \mathrm{CRL})$ buffalo foetuses. The canalization of primary duct was found at 120 to 146 days in buffalo foetuses [26].

The primary duct was observed at day 80 in bovine [23] and at $15.0 \mathrm{~cm}$ CRL (60 days) in sheep foetus [9]. It sunk deeper into the teat base at $12.5 \mathrm{~cm}$ CRL (64 days) in goat foetuses [25]. The primary duct was reported at $11.50 \mathrm{~cm}$ CRL in goat foetuses [11]. This structure got extended as a cellular cord and entered deep into the base of the teat at $12.50 \mathrm{~cm}$ CRL.

Numerous secondary ducts were found at 80 days of sheep foetuses [9,27], at 254 days in buffalo foetuses [26], and at $13.8 \mathrm{~cm}$ CRL ( 68 days) in goat foetuses [25]. The secondary ducts were budding off at different angles to the proximal end of the primary duct in various directions between 14 and $17 \mathrm{~cm}$ CRL (69-78 days) in goat foetuses.

Development of teat was found at 80 days of gestation in bovine foetuses [28]. The development of teat was initiated by an elevation of epidermal cone surrounding the mammary bud at $5.70 \mathrm{~cm}$ CRL in buffalo fetuses [20], whereas [11, 25] a papilla was observed like teat discernible on either side of midline in inguinal region between two thighs at $9.5 \mathrm{~cm}$ CRL (58 days) and $6.70 \mathrm{~cm}$ CRL, respectively, in goat foetuses.
The fat pad was found at day 140 and day 80, respectively, in sheep foetuses $[9,27]$. Reference [26] found fat pad at 120 days of foetal life in buffalo. The latter was observed on the base of the developing mammary gland at 180 days of gestation in cattle [21]. The fat pad was reported at $19.5 \mathrm{~cm}$ and $20.0 \mathrm{~cm}$ CRL, respectively, in goat foetuses [11, 25].

Gland cistern was found at 17.00 to $21.00 \mathrm{~cm}$ CRL in cow foetus and $[9,18]$ found the gland cistern near the proximal end of primary duct at day 80 in sheep foetuses. All the ducts were luminized at $38.6 \mathrm{~cm}$ CRL (139 days) [25], whereas gland cistern between the fat pads was observed at $17.60 \mathrm{~cm}$ CRL in goat foetuses [11].

The streak canal was the distal most part of the primary duct that canalised at last but lumen was not fully formed up to 152-182 days in buffalo foetuses [26]. The streak canal and teat cistern were reported at 100 days in bovine foetuses [23] and at 80 days in sheep foetuses [9].

Teat cistern was described at 120 days of gestation in mammals [21, 24]. The teat canal was found at $21.7 \mathrm{~cm}$ CRL (91 days) in goat foetuses [25].

Nerves and small blood vessels formed in close association with each bundle of developing adipose tissue at day 80 and elastic fibres at day 90 in sheep foetuses [9]. The numerous blood capillaries invaded the bud at $4.4 \mathrm{~cm}$ to $6.0 \mathrm{~cm}$ CRL (44-49 days) and $7.20 \mathrm{~cm}$ CRL in goat foetuses, respectively [11, 25].

The distinct epidermis and dermis were observed between 74 and 115 days of gestation in buffalo [29]. The epithelium was divided into 4 layers on stratum germinativum, stratum granulosum, stratum intermedium, and stratum basale goat foetus [30], whereas distinct dermis was reported between 74 and 115 days of gestation in buffalo foetuses.

The first evidence of hair follicle was found at 102 days in buffalo foetuses [31, 32]. The hair follicles began to develop around the 120th day of gestation in bovines [21]. The hair 
follicle was observed on the teat at 65 days in goat foetuses [12].

The sweat gland was found at 140-150 days buffalo foetuses [29]. The primordium of sweat glands was observed at 139 days in buffalo foetus [31]. The sweat glands were seen for the first time at 83 days in goat foetuses [12]

The sebaceous glands were reported at 158 days in buffalo foetuses [31]. It was associated with each primary follicle at 120 days in sheep foetuses [9]. A bunch of sebaceous glands were reported around the hair follicles in 117-139 days in goat foetuses [12].

\section{Conflict of Interests}

The authors declare that there is no conflict of interests regarding the publication of this paper.

\section{References}

[1] D. Chaurasia, Histochemical and Ultrastructural studies on mammary gland in buffalo (Bubalusbubalis) [Ph.D. thesis], Maharashtra Animal and Fishery Sciences University, Nagpur, India, 2009.

[2] H. T. Huynh, G. Robitaille, and J. D. Turner, "Establishment of bovine mammary epithelial cells (MAC-T): an in vitro model for bovine lactation," Experimental Cell Research, vol. 197, no. 2, pp. 191-199, 1991.

[3] A. C. Lopez, Characterization of Differentiation of Bovine Mammary Epithelial Cells [Honours Scholar Thesis], University of Connecticut, 2011.

[4] V. K. Taneja and P. S. Birthal, "Role of buffalo in food security in Asia," in Proceedings of 4th Asian Buffalo Congress, pp. 1-12, New Delhi, India, 2003.

[5] S. P. S. Ahlawat, P. K. Vij, and M. S. Tantia, "Conservation of buffalo genetic resources," in Proceedings of 4th Asian Buffalo Congress, pp. 62-68, New Delhi, India, 2003.

[6] A. R. Rowson, K. M. Daniels, S. E. Ellis, and R. C. Hovey, "Growth and development of the mammary glands of livestock: a veritable barnyard of opportunities," Seminars in Cell and Developmental Biology, vol. 23, pp. 557-566, 2012.

[7] H. Eitedal, M. H. El-Sayed, E. O. H. El-Shafie, A. A. Saifelnasr, and E. E. Abu, "Histological and histochemical study on mammary gland of Damascus goat at milking stages," Egyptian Journal of Sheep and Goat Sciences, vol. 4, no. 1, pp. 75-88, 2009.

[8] C. H. Knight and M. Peaker, "Development of the mammary gland," Journal of Reproduction and Fertility, vol. 65, no. 2, pp. 521-536, 1982.

[9] C. M. C. Jenkinson, The pattern and regulation of mammary gland during foetal life in the sheep [Ph.D Dissertation], Massey University, Palmerston North, New Zealand, 2003.

[10] K. S. Roy, N. Sood, and P. P. Gupta, "Enzyme histochemistry of mammary gland of goat (Capra hircus)," Indian Journal of Animal Sciences, vol. 67, no. 9, pp. 772-773, 1997.

[11] R. Vaish, Histological, Histochemical and Ultrastructural Studies of Mammary Gland in Prenatal and Postnatal Non Descript Goats, JNKVV Jabalpur, Madhya Pradesh, India, 2012.

[12] S. Chaurasia, K. M. Panchal, Y. L. Vyas, and M. C. Desai, "Histomorphological study on skin and its Adnexa on the Mammary Glands of Prenatal Non descript goat," Indian Journal of Veterinary Anatomy, vol. 21, no. 1, pp. 40-42, 2009.
[13] M. J. Edwards, "Observations on the anatomy of the reproductive organs of cows with special reference to those features sought during examination per rectum," New Zealand Veterinary Journal, vol. 13, no. 2, pp. 25-37, 1965.

[14] M. K. Soliman, "Studies on the physiological chemistry of the allantoic and amniotic fluids of buffalo at various periods of pregnancy," Indiana Veterinary Journal, vol. 52, pp. 106-111, 1975.

[15] L. G. Luna, Manual of Histological Staining Methods of Armed Forces Institute of Pathology, McGraw Hill, New York, NY, USA, 1968.

[16] G. W. Robinson, "Cooperation of signalling pathways in embryonic mammary gland development," Nature Reviews Genetics, vol. 8, no. 12, pp. 963-972, 2007.

[17] R. R. Anderson, "Embryonic and foetal development of the mammary apparatus," in Lactation. A Comprehensive Treatise, B. L. Larson, Ed., pp. 3-40, Academic Press, New York, NY, USA, 1978.

[18] E. J. Carroll, "Lactation," in Veterinary Endocrinology and Reproduction, L. E. McDonald, Ed., pp. 513-528, Elia and Febiger, Philadelphia, Pa, USA, 3rd edition, 1980.

[19] S. E. Ellis, Mechanisms controlling ductal morphogenesis in the ruminant mammary gland [Ph.D Dissertation], Virginia Polytechnic Institute and State University, Blacksburg, Va, USA, 1998.

[20] K. M. Panchal, K. N. Vyas, and Y. L. Vyas, "Organogenesis of the mammary gland in the female surti buffalo (Bubalusbubalis) I. Development from mammary line to sprout," Buffalo Journal, vol. 2, pp. 171-177, 1998.

[21] T. A. McGeady, P. J. Quinn, E. S. F. Patrick, and M. T. Ryan, Veterinary Embryology, Blackwell Publishing, London, UK, 2006.

[22] J. D. Turner and H. T. Huynh, "Role of tissue remodeling in mammary epithelial cell proliferation and morphogenesis," Journal of Dairy Science, vol. 74, no. 8, pp. 2801-2807, 1991.

[23] R. M. Akers, "Overview of mammary development," in Lactation and the Mammary Gland, R. M. Akers, Ed., pp. 3-44, lowa State Press, Ames, Iowa, USA, 2002.

[24] P. Hyttel, F. Sinowatz, and M. Vejlsted, Essentials of Domestic Animal Embryology, Elsevier Saunders, Philadelphia, Pa, USA, 2010.

[25] S. Chaurasia, K. M. Panchal, Y. L. Vyas, and M. C. Desai, "Organogenesis and Histogenes is of Mammary Gland in female goat (Capra hircus)," Indian Journal of Veterinary Anatomy, vol. 24, no. 2, pp. 67-70, 2012.

[26] N. Singh, Age correlated histomorphological and histochemical studies on the mammary gland of Indian buffalo (Bubalusbubalis) [M.S. thesis], Punjab Agricultural University, Ludhiana, Punjab, 2000.

[27] I. A. Forsyth, G. Gabai, and G. Morgan, "Spatial and temporal expression of insulin-like growth factor-I, insulin-like growth factor-II and the insulin-like growth factor-I receptor in the sheep fetal mammary gland," Journal of Dairy Research, vol. 66, no. 1, pp. 35-44, 1999.

[28] L. G. Sheffield, "Organization and growth of mammary epithelia in the mammary gland fat pad," Journal of Dairy Science, vol. 71, no. 10, pp. 2855-2874, 1988.

[29] D. M. Bhayani, K. M. Panchal, K. N. Vyas, and G. Baishya, "Histomorphological study on prenatal development of skin in surtibuffaloes," The Indian Journal of Animal Sciences, vol. 62, pp. 421-423, 1992.

[30] M. R. Malik, M. Tripathi, M. SrivastavaA, and J. S. Taluja, "Histogenesis of epidermis in goats," in Proceedings of 11th Convention of IAVA, 1996. 
[31] K. M. Panchal, K. N. Vyas, and Y. L. Vyas, "Histogenesis of skin and its adenexaof surtibuffalo," Indian Journal of Veterinary Anatomy, vol. 11, no. 2, pp. 158-160, 1999.

[32] R. Singh, Study on histogenesis of skin in Indian buffalo (Bubalusbubalis) [M.S. thesis], Guru Angad Dev Veterinary and Animal Sciences University, Ludhiana, Punjab, 2006. 

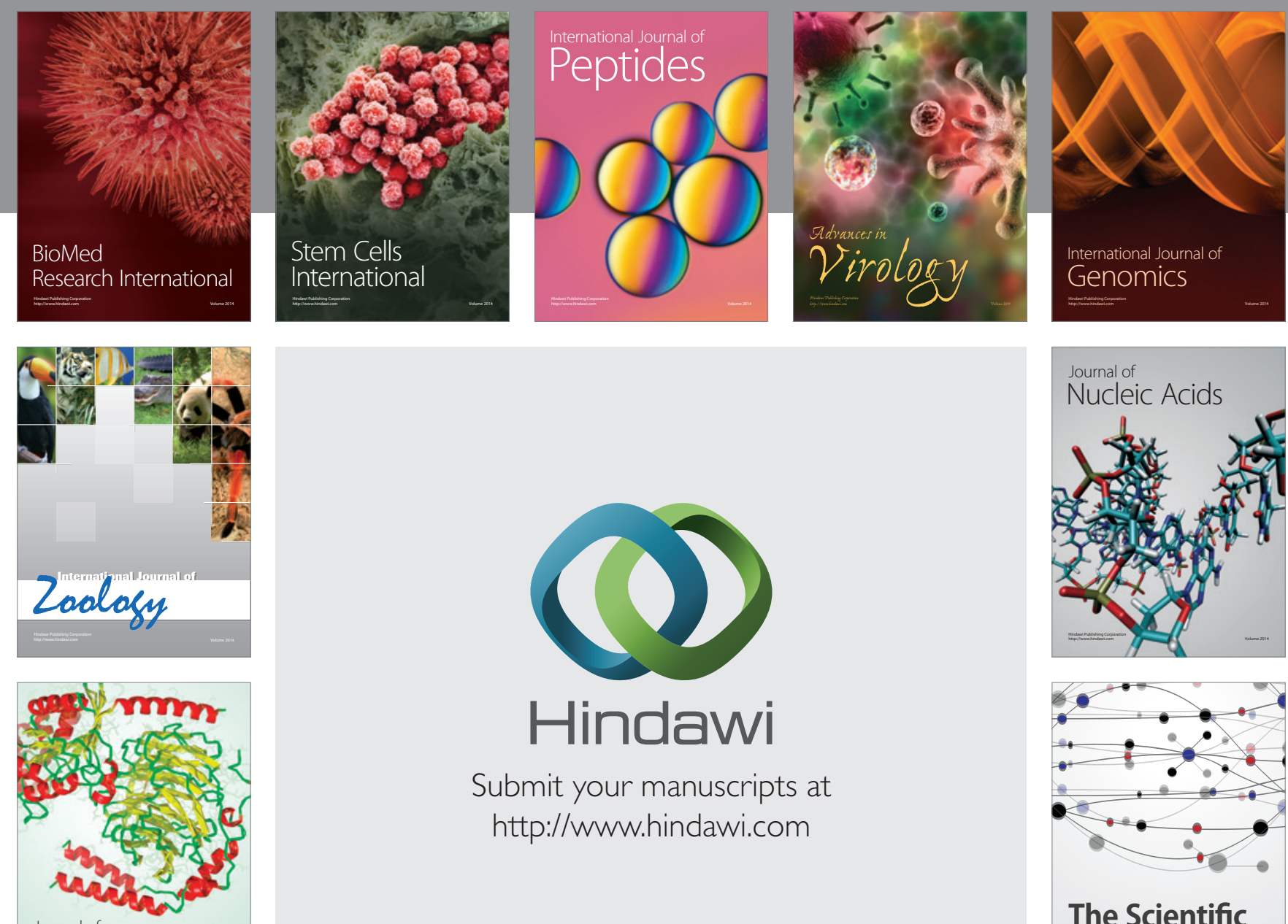

Submit your manuscripts at

http://www.hindawi.com

Journal of
Signal Transduction
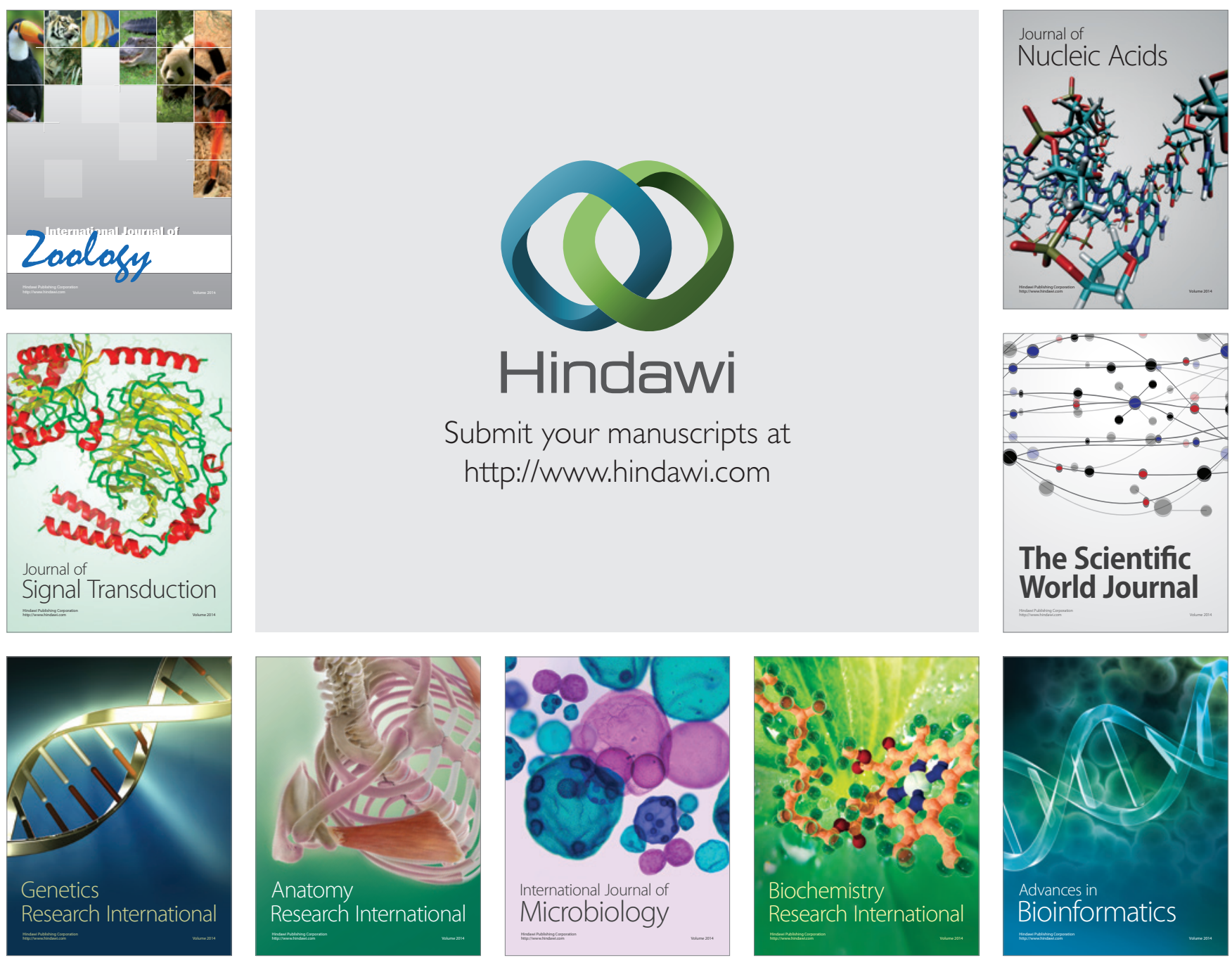

The Scientific World Journal
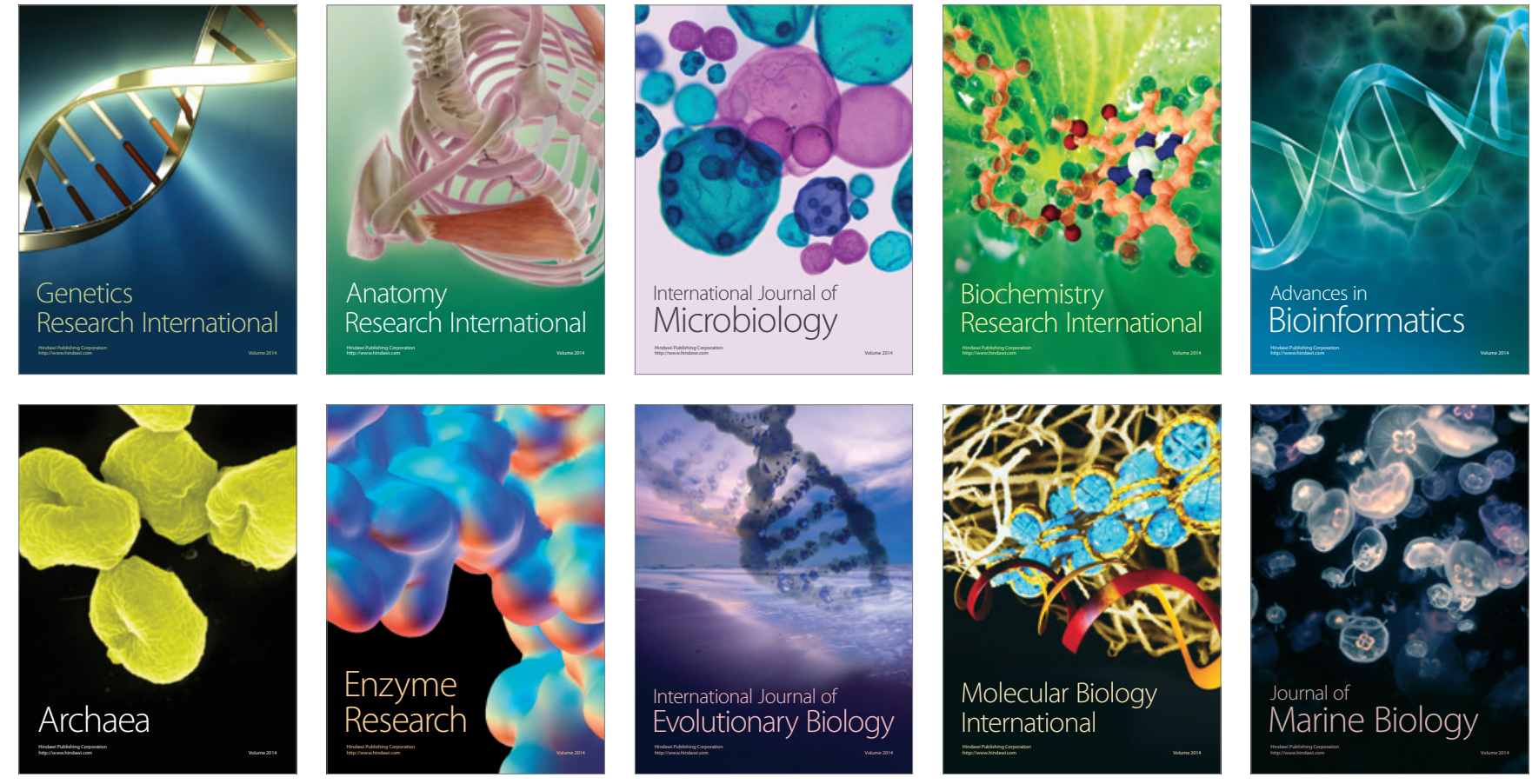